\title{
The elephant at the fence: almsman, panhandler, friend or foe?
}

\author{
Prithiviraj Fernando $^{1}$ (D) Sampath K. K. Ekanayaka ${ }^{1} \cdot$ Jennifer Pastorini ${ }^{1,2}$ (D)
}

Received: 24 June 2020 / Revised: 20 October 2020 / Accepted: 26 October 2020 / Published online: 5 November 2020

(C) The Author(s) 2020

\begin{abstract}
Feeding of wild Asian elephants at the Udawalawe National Park perimeter electric fence by the general public is longstanding. We monitored the elephants and feeding activities, and conducted questionnaire surveys of stakeholders. Over 50 individual adult male elephants engaged in the activity. The exclusive male presence was consistent with a high-risk high-gain male strategy. The elephants were mostly offered fruits and vegetables. Over a thousand people a day watched and fed the elephants. Most people bought food for elephants from roadside stalls and vendors had significantly more sales if elephants were present. The feeding of elephants brought significant economic benefit to communities bordering the park. We found the impacts of feeding on the elephants and environment to be largely neutral. Impacts on people and conservation were mainly positive. Actions taken by authorities to stop the feeding have targeted the elephants and resulted in the decrease of feeding but not its elimination. Managing the activity instead would help increase economic benefits and ensure safe interaction between people and elephants. Such management, by directly benefitting local communities, could make them partners in the conservation process and form the basis of an effective outreach program.
\end{abstract}

Keywords Wildlife provisioning $\cdot$ Feeding wild animals $\cdot$ Human-wildlife interaction $\cdot$ Protected area outreach $\cdot$ Asian elephant

\section{Introduction}

Human-wildlife interactions encompass an array of occurrences that may positively or negatively impact one or both actors. In many cases, the outcomes are complex and contentious. For example, hunting benefits people by providing food, revenue and recreation. It is clearly detrimental to hunted individuals and many species have been hunted to extinction (Loveridge et al. 2009). Illegal hunting or poaching is universally accepted as detrimental to wildlife. However, regulated hunting may benefit species, eco-systems and conservation through creating interest in the hunted species and providing revenue that can be used for conservation (Loveridge et al. 2009; Treves 2009). Wildlife tourism provides economic, psychological and emotional benefits to people. The revenue it generates positively effects protected area management, hence conservation (Higginbottom and Tribe

Jennifer Pastorini

jenny@aim.uzh.ch

1 Centre for Conservation and Research, Tissamaharama, Sri Lanka

2 Anthropologisches Institut, Universität Zürich, Zürich, Switzerland
2004). Tourism may also have negative impacts on wildlife (Green and Giese 2004). Crop and livestock depredation by wildlife is detrimental to people and crop defence often harms wildlife. However, better nutrition may outweigh the costs of procurement for raiders (Warren et al. 2011).

Feeding of wildlife by habitat modification and intentional or unintentional food provisioning is widespread (Newsome and Rodger 2008). Provisioning captive or semi-captive animals may ensure their survival while furnishing nature experiences for providers, who gain religious, cultural and emotional fulfilment (Orams 2002). Intentional food provisioning of free-ranging animals is generally considered detrimental to wildlife, but may also have positive outcomes (Orams 2002; Dubois and Fraser 2013a). It may also have negative impacts on people and create public safety concerns (Dubois and Fraser 2013a). However, supplemental feeding has been instrumental in the recovery of critically endangered species and is a feature of most reintroduction programs (Orams 2002).

Intentional food provisioning of particular groups of wildlife is universal and extensive (Dubois and Fraser 2013a). For example, millions of people feed birds. Annual quantities of birdseed dispensed in the UK and the USA alone amount to 60 million and 500 million $\mathrm{kg}$, respectively (Brittingham and Temple 1992; Fuller et al. 2008; Cox and Gaston 2018). 
The Asian elephant (Elephas maximus) is globally endangered and listed in CITES Appendix I. Free-ranging Asian elephants are currently restricted to 13 south and southeast Asian countries. Sri Lanka is unique in that the majority of its elephants share the landscape with people (Fernando et al. in press). Elephants take refuge in forests during the day, venturing out to raid crops at night and people confront them, attempting to prevent raiding. The ensuing human-elephant conflict causes the death of around 250 elephants and 70 people annually in Sri Lanka (Fernando et al. 2011). While eastern cultures and religions have a close and longstanding association with elephants, cultural and religious associations are mostly with captive elephants.

\section{Food provisioning of elephants in Udawalawe}

Around 2003 people started feeding an adult male known as 'Rambo' that was frequenting the electric fence on the southern border of the Udawalawe National Park. With time, the number of elephants coming to the fence increased and an industry of supplying fruits and vegetables to feed the elephants flourished. Most wildlife enthusiasts were against it, as they viewed elephants at the fence as 'beggars'. Wildlife Department officers opposed it, assuming loss of park revenue by people observing elephants at the fence instead of visiting the park.

People mostly stood on the roadside and threw the food to the elephants. On rare occasions, they attempted to hand-feed them. Some people also petted the elephants. On at least two occasions, people crept under the fence and approached elephants, and were attacked and injured.

\section{Control measures}

In 2011, the Wildlife Department put up signboards banning feeding of elephants and threatening violators with prosecution. In addition, wildlife officers patrolled the road and chased away elephants with firecrackers or shooting with shotguns. Failure of these measures to stop the feeding led to the construction of a second electric fence $50 \mathrm{~m}$ inside the park and paralleling the perimeter fence in 2012. Simultaneously, chasing of elephants was intensified. While initially successful, inner fence breaches increased with time and it became non-functional by about 2017. Elephants again started coming to the perimeter fence frequently. Concurrently, elephants breaking the perimeter fence and raiding crops increased, leading to fence modification by offsetting the live wires and replacing concrete posts with wooden posts. In 2018, night patrolling by tractors with armed personnel was resumed. In 2019, rolls of concertina wire were laid between the two fences. While elephants also exited the fences on the other boundaries and raided (Ranjeewa et al. 2015), measures such as the second fence, concertina wire and patrolling were implemented only on the southern boundary.

Dubois and Fraser (2013a) suggested evaluating food provisioning of wild animals, based on its effect on conservation and animal welfare, and the ability to control the activity. Here, we assess the feeding of elephants at Udawalawe and discuss the implications of our findings on impacts on elephants, environment, people and conservation, and for managing the activity.

\section{Material and methods}

\section{Study site}

The Udawalawe National Park is situated in southern Sri Lanka between $6^{\circ} 34^{\prime} 50^{\prime \prime}-6^{\circ} 24^{\prime} 50^{\prime \prime} \mathrm{N}$ and $80^{\circ} 46^{\prime} 14^{\prime \prime}-81^{\circ} 00^{\prime}$ $40^{\prime \prime} \mathrm{E}$. The road linking the townships of Udawalawe and Thanamalwila lies on the southern boundary of the park (Fig. 1) and is one of the main access roads to the south of the country. Directly south of the park is a large sugarcane plantation, which was intensively raided by elephants in the 1980s. Initially night patrolling of the perimeter road with tractors and armed personnel was implemented but failed to stop raiding. Subsequently, an electric fence was put up on the southern boundary of the park, which was later extended to enclose the entire park with two 'corridors' in the north and east (Fig. 1).

Human-elephant conflict occurred all around the park. Monitoring three locations in a 6-km fence segment on the northern boundary found 35 adult males regularly crossing the electric fence to raid (Ranjeewa et al. 2015). Some elephants also broke the southern perimeter fence at night, raided sugarcane and paddy fields and broke back into the park at dawn.

\section{Monitoring of elephants and stalls}

We drove for $25 \mathrm{~km}$ on the Udawalawe-Thanamalwila road on 59 occasions from 19 January 2011 to 15 April 2013 and enumerated the elephants at the fence and open vegetable stalls. Elephants within $25 \mathrm{~m}$ of a point directly opposite a stall were deemed to be opposite it. Elephants within $50 \mathrm{~m}$ of each other were considered associating. The survey of elephants was repeated on 18 days from 7 May 2019 to 19 October 2019.

On 24 days between 19 January and 27 December 2011, elephants at the fence were photographed and individually identified based on morphological characters (Fernando et al. 2010). Their body condition was assessed based on a visual score of $0-10$ (Fernando et al. 2009). Photographs of 15 adult males that were observed in the park in 2011, but not at the fence, were also scored for body condition. 
Fig. 1 Map of Udawalawe National Park

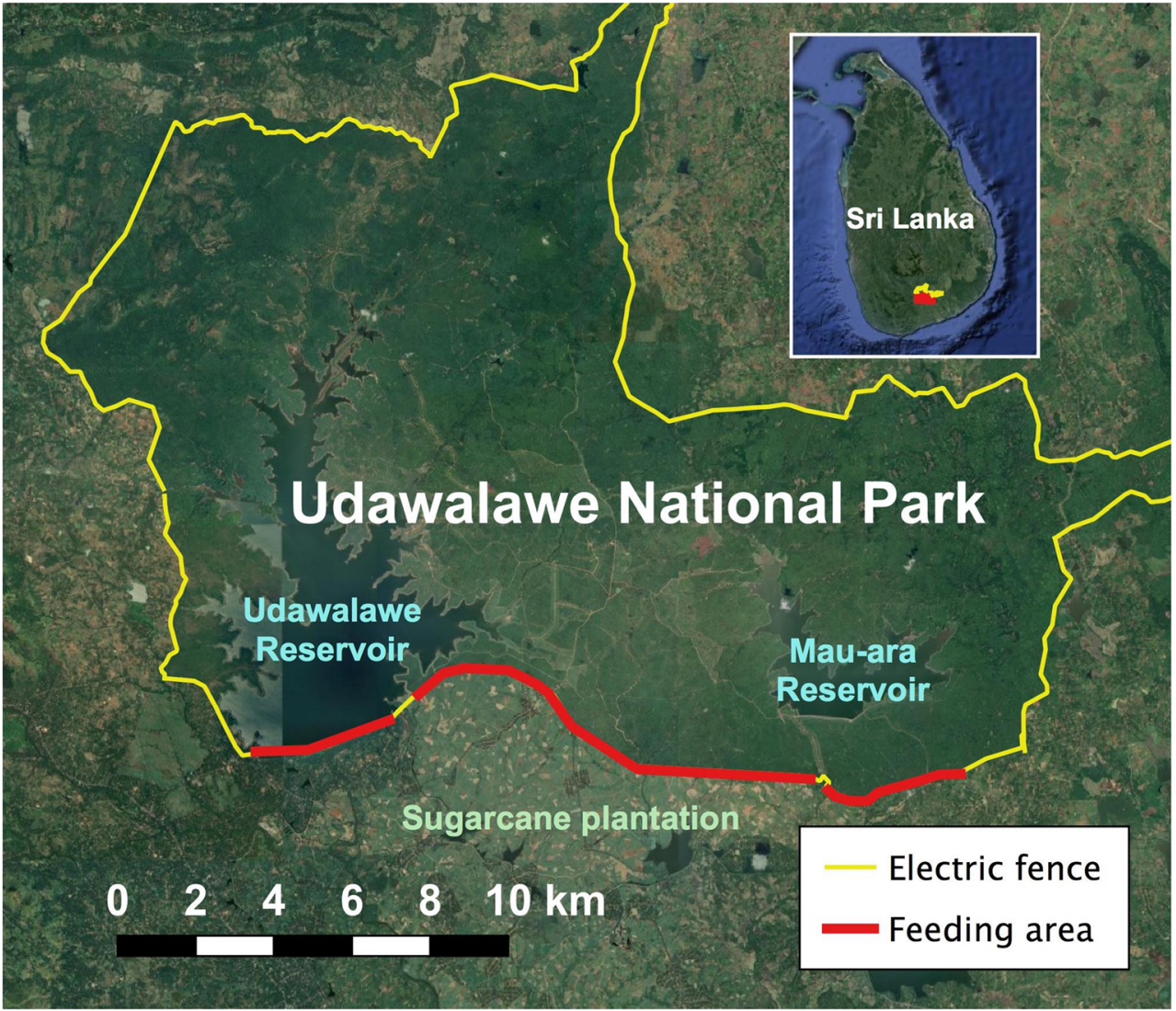

\section{Food offered to elephants}

From 2 to 6 May 2012, we made observations at each elephant, recording and weighing items elephants were offered. We also asked providers whether they bought the food on site or not.

\section{Sales at vegetable stalls}

From 12 to 24 March 2012, we asked two vegetable stall owners to record the time and amount of sales, whether an elephant was present at the time of the sale and the time period elephants were opposite their stalls.

\section{Interview survey of residents}

From 26 April to 1 May 2012, we conducted a questionnaire survey of residents along the Udawalawe-Thanamalwila road. We asked if they sold vegetables or fruits, and if elephants were beneficial to them or their area. We also queried their opinion of the second fence.

\section{Interview survey of people stopping for elephants}

From 2 to 5 May 2012, we interviewed one person per party stopping for the elephants. We asked about their travel plans, experience with national parks and their thoughts on the fence elephants.

\section{Assessing the number of vehicles}

From 17 August to 19 October 2019, we recorded the number of vehicles that stopped for elephants.

\section{Results}

\section{Monitoring of elephants}

We identified 50 individual elephants that were fed by people in 2011. Over the 24 sampling days, on average an individual elephant was sighted on $5.64 \pm 4.75$ (range 1-17) days (Fig. 2 ). About half (52.0\%) of the elephants were seen 1-3 times.

The average number of elephants observed per sampling period from 2011 to 2013 was $10.1 \pm 6.0$ (range $0-29, n=$ 593; Fig. 3) and in 2019, it was $3.2 \pm 1.5$ (range $1-6, n=18$ ).

All elephants observed at the fence were males. The average body condition of the 50 individual fence elephants was $5.7 \pm 0.6$ (range 5-7) and of the 15 park males $5.6 \pm 0.8$ (range 4-7), which were similar $(P=0.8548)$. Of all elephants recorded at the fence, $46.2 \%$ were single while $53.8 \%$ had one 


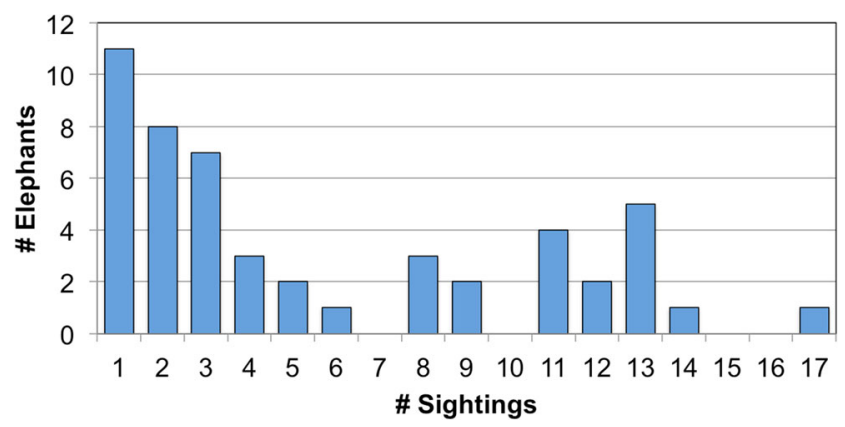

Fig. 2 Frequencies individual elephants were sighted in 2011

or more companions (Fig. 3). From 2011 to 2013, a majority $(87.0 \%)$ of fence elephants were opposite a vegetable stall.

\section{Food offered to elephants}

Feeding of elephants was observed for a total of $18 \mathrm{~h} 5 \mathrm{~min}$ over 5 days. A total of 509 feeding events were recorded in which $541.1 \mathrm{~kg}$ of food was offered. The average offering was $1.1 \pm 2.1$ (range 0.01-30) $\mathrm{kg}$. The average number of elephants present during feeding was $3.0 \pm 1.3$ (range 1-6). An average of $14.3 \pm 8.1 \mathrm{~kg}$ of food was offered per hour, which amounted to an average of $5.3 \pm 2.7 \mathrm{~kg}$ of food $/$ elephant $/ \mathrm{h}$. On average, an elephant remained at a location for 1:49 $\pm 1: 13 \mathrm{~h}$ $(n=31)$.

Maize $(29.4 \%)$, bananas $(28.6 \%)$ and watermelons $(26.9 \%)$ were the most common items elephants were offered (Fig. 4). Prepared food such as bread or cookies was given 12 times $(2.4 \%)$. People bought the food from stalls in $60.6 \%$ of instances and the rest brought it with them.

\section{Sales at vegetable stalls}

From 2011 to 2013, we enumerated 33.7 \pm 10.2 (range 13-65) vegetable stalls per survey.

Over the 19 days, the two monitored stalls were open for 10:50 $\pm 0: 39 \mathrm{~h}$ /day and together had a total income of Rs. 29,385 (US\$ 220). There were elephants opposite the stalls on 31 occasions and they stayed an average of $109 \pm 73$ (range 20-345) min. Over the monitored period, the stalls had 177 customers, who spent Rs. 20-750 each on vegetables/fruits. In 110 sales occurring in the presence of an elephant, the average was Rs. $205.8 \pm 141.3(P<0.0001)$ and in 67 sales without elephants Rs. $100.7 \pm 100.3$. In the presence of elephants, there were $2.4 \pm 1.4$ sales $/ \mathrm{h}$ and without elephants $0.5 \pm 0.3$ sales/h $(P<0.0001)$. The income per hour with an elephant was on average Rs. $506.8 \pm 326.0$ and Rs. $45.3 \pm 37.8$ without $(P<0.0001)$.

\section{Interview survey of residents}

For $77.5 \%$ of the 122 interviewed respondents, the main source of income was farming. A total of $74(72.5 \%)$ of respondents operated a roadside vegetable stall at some time with $32(31.4 \%)$ doing so currently and 42 (41.2\%) previously. The 42 terminated stalls were in business on average for $5.1 \pm 5.1$ years. Lacking elephants opposite their stall was the reason for $40.5 \%$ to close shop.

Of the 74 vendors, $29.7 \%$ stated that the revenue earned from their stall was part of their main income and the remaining $70.3 \%$ said that it was supplementary.

Five vendors $(6.8 \%)$ sold produce from their home gardens. Others sourced produce from neighbourhood home

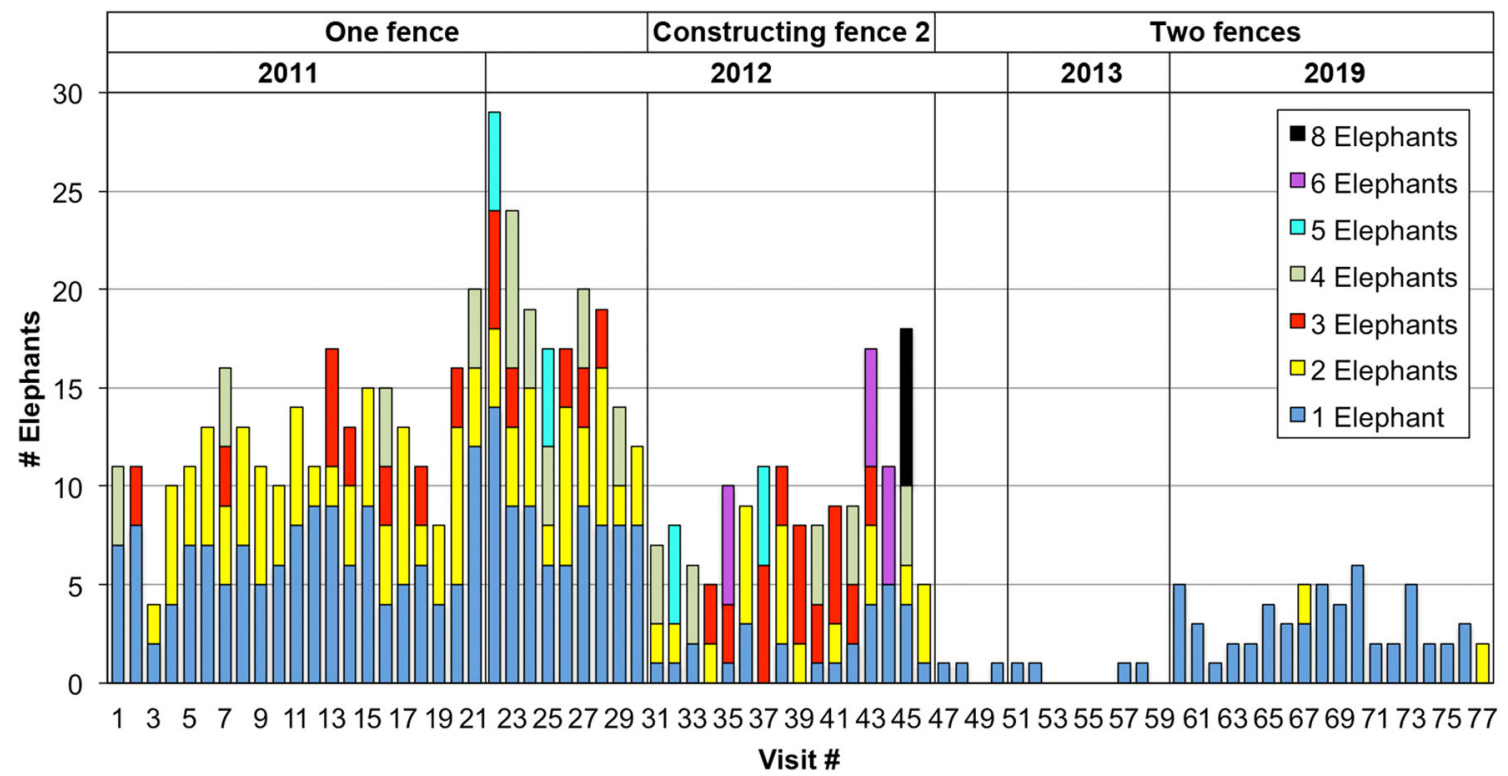

Fig. 3 Number of fence elephants observed per sampling period 
Fig. 4 Types of food given to elephants

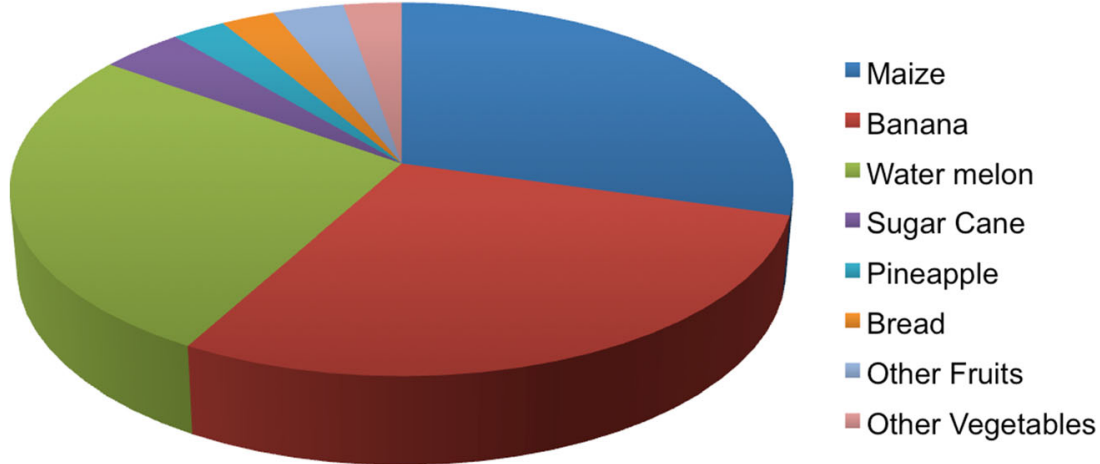

gardens (37.8\%), from the general area (48.6\%) and/or bought from a wholesale truck $(29.7 \%)$. Of the vendors, $54.7 \%$ stated they sold over 5 times the usual amount if elephants were present, $10.9 \% 2-5$ times and $17.2 \%$ said it doubled sales. One person felt the presence of elephants decreased sales and the remaining $15.6 \%$ said elephants made no difference.

Over half (56.9\%) of interviewed residents felt positively about elephants at the fence, $32.4 \%$ did not approve of it and $10.8 \%$ were ambiguous. When asked if they benefitted from the fence elephants, $31.7 \%$ said they had no benefit, $43.3 \%$ said they benefitted from produce sales and $25.0 \%$ by seeing elephants. All respondents stated that fence elephants brought benefits to the area and all felt that road users benefitted since they got to see elephants.

When asked about the internal fence, $41.6 \%$ approved it, $49.5 \%$ disapproved and 9 had no opinion. The majority (97.1\%) thought it would decrease the income of people living next to the park.

When queried if they benefitted from the park other than through fence elephants, the majority $(72.0 \%)$ said that they did not, while $28.0 \%$ said they did. Most (77.5\%) respondents had never visited the park.

\section{Interview survey of people stopping for elephants}

We interviewed 102 groups, totalling 704 people, of which $23.4 \%$ were children. The average group size was $6.9 \pm 6.3$ (range 1-50) persons. Half the groups (52.9\%) were on pilgrimage and $29.4 \%$ on social visits.

Of the 102 respondents, $82.5 \%$ had visited a national park at least once and $28.6 \%$ had visited Udawalawe National Park. When asked whether observing the fence elephants would influence their visiting Udawalawe National Park, $24.8 \%$ stated they were now more likely to go, $4.0 \%$ less likely and 71.3\% that it made no difference.

When asked what they thought about elephants standing at the fence, $91.2 \%$ liked it and $7.8 \%$ felt it was bad. One person thought it was good and bad. People liked it because it was nice to see them $(71.3 \%)$, they enjoyed the experience $(22.3 \%)$ and/or for some other reason (15.9\%).
Of the respondents, $88.9 \%$ knew of the elephants before coming, while for $11.1 \%$, it was unexpected. Twenty-three $(22.8 \%)$ did not feed the elephants. Others fed the elephants because they liked it (45.6\%), for religious reasons (19.0\%, as alms giving) or for both (32.9\%). Two people thought the elephants had insufficient food in the park. When asked about the internal fence, $85.3 \%$ did not like it, $10.8 \%$ thought it a good idea and 4 had no opinion.

\section{Number of vehicles and people}

During 10 days, over a period of $700 \mathrm{~min}$, we recorded a total of 646 vehicles stopping for elephants, of which $25.1 \%$ were motorbikes or three wheelers, $35.8 \%$ cars, $31.1 \%$ vans and $8 \%$ buses. Taking the average group size as 6.9 people from the interview survey, we estimated the number of people stopping for elephants as 382.1 people per hour or 4585 people per day (12 h).

\section{Discussion}

Intentional feeding of wild elephants at Udawalawe by the general public has been ongoing for many years. With the possible exception of bears (Tate 1983; Gray et al. 2004; Dubois and Fraser 2013b), intentional food provisioning of large and potentially dangerous wild animals is uncommon. Many such instances are in the aquatic realm and conducted by tourism operators to enhance wildlife sightings, as in great white sharks (Laroche et al. 2007), whale sharks (Meekan and Lowe 2019), rays (Semeniuk et al. 2007), dolphins (Orams 1995) and crocodiles (Ryan 1998). We found no previous references to the large-scale and long-term feeding of potentially dangerous completely wild mega-fauna by the general public. Thus, the described feeding of wild elephants in Udawalawe is arguably a unique human-wildlife interaction.

We found 50 individual male elephants coming to the fence in 2011 alone. A total of around 250 males use the Udawalawe National Park (de Silva et al. 2011). Thus, over one-fifth of the 
males in the park engaged in the activity, suggesting that the food provided was a major attractant.

Elephants have a sexually dimorphic social organisation with group-living females and young and largely solitary adult males (Fernando and Lande 2000). Males take greater risks in a high-risk high-gain strategy and most human-elephant conflict incidents are due to males (Sukumar 1995; Fernando et al. 2010). Elephants perceiving people as a threat but engaging with them to obtain food is consistent with a 'high-risk highgain' male strategy and could explain the exclusive male composition of fence elephants.

Since females live in groups, their absence could also be due to the quantity of food available at a location being inadequate to provide for all members of a group. However, the high frequency of observed male associations at feeding locations suggests otherwise. Additionally, female Asian elephant society is fluid with females foraging alone at times (Fernando and Lande 2000). Therefore, resource magnitude cannot explain the complete absence of females.

\section{Behavioural alteration}

Provisioning may engender novel behaviours and alter foraging patterns. Their impact on activity budgets can be considerable. For example, provisioned baboons foraged for $20 \%$ and rested for $50 \%$ of the time, while non-provisioned baboons foraged for $60 \%$ and rested for $10 \%$ (Altmann and Muruthi 1988). Dingoes dependent on natural food were mobile $81 \%$ of the time, whereas those exploiting human-sourced food rested for 52\% (Déaux et al. 2018). However, such changes are not universal. No difference in activity budget or wild foraging patterns was observed between troops of wild foraging white-faced capuchins and those with a $50 \%$ anthropogenic diet (McKinney 2011). Although previously claimed, there were no substantiated behavioural differences between whale sharks from a provisioning site and from nonprovisioned sites (Meekan and Lowe 2019).

Of elephants engaging in the activity, the proportion observed in a given sampling period varied but never approached unity and none were observed in all sampling periods. Therefore, elephant presence at the fence was episodic. We also found individuals to spend around $2 \mathrm{~h}$ at a feeding location. Thus, provisioning may not have caused a significant deviation in their time budget. However, if elephants moved between feeding locations, or returned, fence time could be considerable. In Sri Lanka, Eisenberg (1980) estimated a 24-h time budget for elephants as $76 \%$ feeding, $12 \%$ moving and $13 \%$ resting, drinking and bathing. Males in Gal Oya spent $87.1 \%$ of the time feeding and $10 \%$ walking while those in Lahugala fed for $93.5 \%$ and walked $1.9 \%$ of the time (McKay 1973). In the Nilgiris in India, elephant time budgets varied by habitat, with $41.0-68.0 \%$ feeding, 11.6-29.7\% moving and 15.7-22.3\% resting (Baskaran et al. 2010). Therefore, while feeding is always the major component, elephant time budgets are highly plastic and it is likely that any deviation due to feeding at the fence was within the bounds of natural variation.

Elephants foraging naturally consume around $150 \mathrm{~kg}$ by feeding for about 17-19 h a day (Vancuylenberg 1977), which amounts to an intake of about $7.8-8.8 \mathrm{~kg} / \mathrm{h}$. Fence elephants received around $5.3 \mathrm{~kg} / \mathrm{h}$, which was slightly less than that obtained in the wild.

Foraging theory predicts goals that maximise nutritional gains or minimise feeding time (Schmitz 1990), both of which are realised in provisioning. Therefore, provisioned animals could be expected to feed exclusively on provided food. However, studies have found them to continue normal foraging. Response of great white sharks to provisioning decreased with time (Laroche et al. 2007). Provisioned magpies continued to forage naturally and the majority of their diet consisted of natural food (O'Leary and Jones 2006). Winter-provisioned deer continued to forage on natural browse (Schmitz 1990), as did provisioned Barbary macaques (Unwin and Smith 2010) and whitefaced capuchins (McKinney 2011). Foraging is a complex behaviour and may include innate mechanisms. Elephants in Sri Lanka tend to walk about 2-6 km daily (CCR unpublished data). Walking-and-feeding is presumably an adaptation to the dispersed, low-quality food elephants consume. Standing at a feeding station runs counter to such behaviour and after a time, "normal' behaviour may override it.

\section{Dependency}

It has been speculated that provisioned individuals may lose foraging skills, hence suffer upon resource withdrawal (Brittingham and Temple 1992). If elephants spent only short bouts at the fence, they would mostly forage naturally. As fence feeding was diurnal, the elephants would still consume wild forage at night. Therefore, the food provided was likely supplementary and fence elephants are unlikely to be heavily impacted by withdrawal of provisioning.

Offspring of provisioned animals may not develop normal foraging, hence be unable to survive without provisioning (Brittingham and Temple 1992). Provisioning may also interfere with maternal care. Calves of some provisioned bottlenosed dolphins received less maternal care and suffered higher mortality (Foroughirad and Mann 2013). Elephants would learn foraging skills mainly in the early years of herd life. Since the fence elephants were exclusively adult males, impacts related to learning or maternal care did not apply.

\section{Habituation}

Habituation is a response decrement to a repeated stimulus (Rankin et al. 2009). Generally, people's proximity signals potential threat to wild elephants, eliciting fear and avoidance. 
As it did not provoke a negative response by fence elephants, they were habituated to people's proximity. Whether habituation per se is good or bad is controversial (Geist 2011; Rogers and Mansfield 2011; Stringham 2011). Reacting with fear to peoples' presence is detrimental to the welfare of animals where people are not a threat (Rushen et al. 1999). While a flight-or-fight reaction to people may indicate 'wildness', it also means such animals are greatly disturbed. Habituated animals exposed to tourists may still demonstrate anxiety (Maréchal et al. 2016). However, this could be due to incomplete habituation or negative interactions with tourists. The fence elephants gained access to an additional resource by being habituated, hence benefitted from it.

Frequenting human environs due to habituation may put animals at risk. Habituated dolphins suffered greater mortality from boat strikes and entanglement (Christiansen et al. 2016). Provisioned black bears hibernated less and were active longer and more exposed to vehicle strikes, hunting and lethal control (Johnson et al. 2018). In Udawalawe, an electric fence limited the elephants to the park and separated them from people. Therefore, provisioning did not result in elephants frequenting human environs.

Actions by authorities, such as throwing firecrackers and shooting, to prevent elephants coming to the fence, did subject them to injury and stress. Similarly, animals could get entangled and cut by the concertina wire. Punitive action by managers against provisioned animals is not uncommon. Managers take such measures in the belief that they prevent greater harm to the animals and/or people. Rangers used physical threats to assert dominance over macaques in Tibet (Usui et al. 2014). Dingoes in Australia and bears in the USA and Canada provisioned by people are killed by authorities (Dubois and Fraser 2013b). Punitive action against habituated animals by managers is sometimes touted as a reason against feeding (Dubois and Fraser 2013a, b). Whether people can interact with large wild animals safely is controversial and depends on numerous variables in respect to the animals, people and environment (Geist 2011; Rogers and Mansfield 2011; Stringham 2011). Therefore, punitive action against provisioned animals should be decided on, only after assessing the impact of provisioning on animals and/or people in a particular situation. If punitive action becomes the greater threat, that would seem excessive and inappropriate. The feeding at Udawalawe was not detrimental to elephants and danger to people was minimal as long as they stayed outside the fence. Consequently, there was little justification for subjecting the elephants to castigatory actions by managers.

\section{Attraction and aggression towards people}

Animals that are fed are attracted to people and display a response increment to the stimulus of people's presence. Such adaptation may cause problems especially if extrapolated to other circumstances. Although feeding was practiced for over a decade, elephants did not approach tourist vehicles looking for food, inside the Udawalawe National Park. In contrast, at Yala National Park, some elephants damaged vehicles by searching for food, presumably because of previous feeding from vehicles. Instances of people who crept under the fence and approached the elephants being attacked also suggest that the Udawalawe fence elephants identified with the particular interaction in a strong locational context and that it was not extrapolated to other circumstances.

Provisioning may also promote aggression towards people as documented in macaques ( $\mathrm{Fa}$ 1992), dingoes (Déaux et al. 2018), bears (Geist 2011), dolphins (Orams 1995) and cassowaries (Kofron 1999). Offering food may signal supplication to non-human primates, indicating subservience and encouraging dominance behaviour. Provisioned individuals associate humans with food and may aggressively approach or attack them. Feeding aggressors or abandoning food by targeted humans rewards and reinforces aggression. Such a possibility was not applicable to Udawalawe as an electric fence separated elephants and people.

\section{Intra-specific aggression}

Feeding may cause intra-specific aggression by creating point food sources that are monopolised by individuals, as observed in mountain sheep (Lott 1988) and macaques (Hill 1999). Aggression increased during low-provisioning periods in hamadryas baboons (Kamal et al. 1997). Increased intraspecific aggression is most likely to occur in territorial species. However, territoriality is limited to conditions where the exclusive use of defendable and limited resources accrues greater fitness. Elephants are non-territorial, as they rely on widespread and low-quality food. Provisioning may engender territoriality, causing non-territorial species to display territorial behaviour (José-Domínguez et al. 2015). While adult male elephants are mostly solitary (Sukumar 1995), the common occurrence of groups of males at the fence suggests an unusually high level of sociality. A well-established dominance hierarchy related to reproduction exists among male elephants (Hollister-Smith et al. 2007). The operation of such established hierarchies even in non-reproductive social contexts may have tempered overt aggression at the fence and facilitated sociability.

\section{Health}

Provisioning may cause consumption of unsuitable food by animals. Unsuitable items may consist of processed food, items not naturally consumed, as in meat products with herbivores, un-digestible objects that could obstruct or damage the digestive system and items that could cause disease. Given that the fence elephants were mostly given unprocessed fruits 
and vegetables, and the only items that could be considered unsuitable was a minor amount of processed food, impacts from ingestion of unsuitable food were unlikely.

Over-nutrition causing obesity and metabolic disease is another concern with provisioning. The body condition of fence elephants was in the mid-range of the scale and did not differ significantly from those that did not come to the fence. Therefore, our observations do not support their overnutrition.

Although the literature on obesity and metabolic disease in captive animals is extensive (see Bauer et al. 2011), we found few studies of free-ranging animals that demonstrated impacts from provisioning. A study of provisioned and nonprovisioned Northern Bahamian rock iguanas found differences in blood parameters (Knapp et al. 2013). Similarly, fatty acid ratios varied between fed and unfed rays (Semeniuk et al. 2007). An experimental study found increases and decreases in body mass, plasma cholesterol and uric acid in magpies fed different types of food (Ishigame et al. 2006). However, we failed to find any studies demonstrating actual loss of fitness through over-nutrition from provisioning.

Provisioning may promote disease by influencing hostpathogen interactions (Sorensen et al. 2014). Although frequently assumed, evidence of disease consequent to provisioning is rare. López et al. (2009) speculated that feeding stations contributed to feline leukaemia in Iberian lynx, which was disputed by Palomares et al. (2010). Tollington et al. (2015) speculated that provisioning might have played some role in a beak and feather disease outbreak in Mauritius parakeets.

Association between provisioning and disease could occur if provisioned animals congregate in large numbers, facilitating disease transmission (Sorensen et al. 2014). Winterfeeding of elk in Yellowstone since 1910 increased populations, with fed elk aggregating in groups of 260-7400 compared to an average non-fed group size of about 14 (Cross et al. 2007). Fed elk had higher Brucellosis seroprevalence, which was related to length of feeding period but not to population size or density at feeding grounds (Cross et al. 2007). Supplemental feeding of white-tailed deer in Michigan led to greatly increased numbers and was associated with higher bovine tuberculosis prevalence (Miller et al. 2003). While mega-aggregations consequent to provisioning could increase disease transmission, mega-aggregations presumably result from increased reproduction and survival due to provisioning. Thus, potential gains from provisioning appear to be magnitudes greater than losses from disease. Elephants may normally aggregate in groups of over a hundred, whereas the largest group observed at the fence was eight. Therefore, increased disease transmission through aggregation had little relevance to the feeding of elephants at Udawalawe.

Continuously and intensively used feeding points may accumulate leftover food and droppings, which may facilitate bacterial growth and parasite spread. There was little leftover food in Udawalawe as elephants were fed individual items. Greater accumulations of elephant dung than seen at the fence occur naturally at waterholes and resting places. Additionally, parasite prevalence in wild Asian elephants is almost $100 \%$ (Abeysinghe et al. 2017). Therefore, bacterial growth and parasite spread are unlikely to be of any significance in the Udawalawe situation.

\section{Population impacts}

Food provisioning may augment reproduction and survival, thereby changing the population structure and density of provisioned species. Most reintroduction programs rely on supplementary feeding to bolster populations. Urban avian abundance was positively correlated with bird feeding station density (Fuller et al. 2008). The all-male composition of fence elephants ruled out population impacts other than some minor possibility of increased survival.

\section{Impacts on non-target species}

Food provisioning of bobwhites resulted in increased rodent densities around feeding areas and of bobcats preying on rodents (Godbois et al. 2004). A range of mammals utilise backyard birdfeeders (Cox and Gaston 2018). Non-target species impacts are more likely where large quantities of food are dispersed widely and gradually consumed by target species. As the elephants at Udawalawe were individually fed specific items, such impacts are unlikely.

\section{Environmental impacts}

Feeding of wild animals may impact the environment through increased densities around feeding areas. For example, supplementary feeding of moose caused extensive browsing impacts around feeding stations (Gundersen et al. 2004). The frequenting of feeding locations by fence elephants may have impacted vegetation in the immediate vicinity by trampling. However, given the low numbers of elephants and feeding locations relative to the area elephants were fed, such impacts are likely to be minor.

\section{Food provisioning may also have benefits}

While dramatic reports of detrimental health impacts on wildlife from provisioning are common, scientific substantiation is lacking (Orams 2002). In fact, many studies have found the contrary or no difference. For example, fed and unfed chickadees had similar survival (Brittingham and Temple 1992) and provisioned magpies reproduced earlier (O'Leary and Jones 2006). Provisioning increased play in juvenile meerkats (Sharpe et al. 2002). Baboons consuming anthropogenic food 
had shorter inter-birth intervals (Strum 2010). Provisioned Balinese macaques had lower gastrointestinal parasite prevalence than non-fed conspecifics (Lane et al. 2011a). Provisioning was associated with greater body size and coat quality in female Barbary macaques (Maréchal et al. 2016). Boutin (1990), reviewing 138 studies of provisioned terrestrial vertebrates, found supplemented individuals had higher body weights and advanced breeding. Given the decrease in habitat quality in the Udawalawe National Park (Fernando 2015), feeding the fence elephants may have had some, albeit minor, positive impacts on them.

\section{Impact on vendors}

Extrapolating the average daily income and the average number of stalls to a year indicates annual sales of US\$142,678. Similarly, based on sales with and without elephants, elephant presence triggered extra sales worth US\$ 98,842 annually. The perception survey confirmed that elephant presence increased sales. People giving up stalls due to lack of elephants further emphasise the relationship between fence elephants and the local economy. Therefore, the roadside produce vendors greatly benefited from the feeding of elephants.

\section{Impact on residents}

Almost three-fourths of families residing along the park border operated vegetable stalls. The monthly per capita household income in the Moneragala and Hambantota Districts where the Udawalawe National Park is situated was around US\$ 136 in 2012-2013 (Anon. 2015). Thus, the income from the stalls likely had a significant positive impact on livelihoods, which was confirmed by the survey results. Local sourcing of produce by stalls resulted in wider spread of benefits. Most residents felt that they and the area benefitted from the feeding of elephants. Some were negative about fence elephants and about half of those surveyed approved the second fence built to prevent feeding, which is at odds with their expressed benefit from elephants. However, the responses have to be viewed in the light of the Wildlife Department actively campaigning against feeding elephants, including threat of punitive action.

Many residents did not consider the park to be of benefit to them. Although they lived on its border, most had never visited the park, which reflects the general relationship between wildlife watching and rural Sri Lankan villagers.

A possible negative impact of feeding wildlife is raiding. Some residents worried that the fence elephants would break out and raid at night. Wildlife enthusiasts and authorities believed that feeding addicted elephants to human food, hence increased raiding. Escalation of preventive measures indicated increased fence breaking and raiding after the internal fence was built, and could support the belief of addiction and raiding. The main food items given to elephants at the fence were maize, ripe bananas and watermelon. In raiding banana plantations, elephants only consume stems and leaves as bananas are harvested prior to ripening. Maize is not extensively grown in the Udawalawe region but watermelon is. Thus, if feeding at the fence caused raiding, the only cultivation impacted would be watermelon, whereas raiding of paddy and sugarcane was the main issue. The initial reason for fencing the park was the extensive raiding of sugarcane by elephants in the 1980s, which predates any feeding.

Elephants generally raid all food crops in a given area (Ekanayaka et al. 2011). They are naturally attracted to characteristics such as high energy and nutritional content, palatability and ease of harvest that make crops valuable to us. Therefore, elephants do not need 'training' to raid crops and it is unlikely that feeding had any bearing on raiding. Throughout the study, some elephants broke the electric fence at night, passed by the vegetable stalls and raided the sugarcane and paddy fields further afield. After a night of raiding, again passing by the stalls without raiding, they broke the fence and re-entered the park by dawn. Therefore, it is possible that the fence elephants and those raiding were not the same.

However, 'Jekyll and Hyde' behaviour by fence elephants of genial association with people during day and aggressive raiding at night cannot be discounted. If fence elephants did raid, increased raiding after the internal fence could also be because the feeding suppressed raiding and its prevention led to resumption of raiding. Such issues could be easily resolved by radio collaring a few raiding elephants and fence elephants.

\section{Impact on people stopping for elephants}

Extinction of nature experience is linked to urbanisation and has extensive detrimental impacts on people's health and wellbeing (Cox and Gaston 2018). Although a developing country, communion with nature is fast becoming a rare commodity even in Sri Lanka. Our results indicated that well over a thousand non-nature based travellers a day appreciated the fence elephants. Although all those using the UdawalaweThanamalwila road passed by the Udawalawe National Park, only a minority had visited or intended visiting it. In addition to hiring a suitable vehicle and paying park fees, visiting parks and viewing wildlife also need free time and the inclination. Consequently, visiting national parks and viewing wildlife are somewhat of an elitist pastime in Sri Lanka. In contrast, the fence elephants provided a wildlife experience to a very significant number of adults and children that usually did not have the opportunity.

People watching and feeding fence elephants gained pleasure and satisfaction from it and did not view the elephants in a negative light. Predictably, their sentiments regarding the internal fence built to prevent feeding were mostly negative. 
While wildlife authorities assumed that park revenue decreased by elephants being at the fence, our survey results suggest the opposite as more people thought of visiting the park after their 'fence experience'. The morality of such negative attitudes by authorities is also questionable, given that the entire conservation establishment is maintained with public funds.

There were also some negative aspects to the feeding of elephants. Wildlife enthusiasts viewed it as promoting begging by fence elephants. For them, the activity amounted to denigration of a noble beast and nature. A few people engaging in inappropriate behaviour such as hand feeding, petting and approaching elephants by creeping under the fence put themselves at risk. Another undesirable outcome is the possibility of promoting similar interactions in dangerous situations, for example where there is no protective barrier.

\section{Motivation for feeding}

Intentional feeding of free-ranging wildlife is classified as research, management, tourism or opportunistic feeding (Dubois and Fraser 2013a). While the Udawalawe situation overlaps with tourism and is opportunistic, it is not a good fit for either.

A tourist's definition as 'someone visiting a place for pleasure and interest' was applicable to many that fed the elephants, but the feeding was not their destination nor motivation for travel. 'Tourism feeding' as defined by Dubois and Fraser (2013a) is conducted primarily to attract tourists. In Udawalawe, no tourist operators were involved and the Wildlife Department, which is the tourism administrator in the Udawalawe National Park, vehemently opposed it. While the produce vendors obtained revenue from it, they were not its primary movers.

The situation could be termed 'opportunistic feeding' as it was conducted by the roadside, hence somewhat a public space. Dubois and Fraser (2013a) use 'opportunistic feeding' to denote activities such as 'backyard feeding' of 'relatively harmless species', in particular, bird feeding. However, they do include an example of tourists feeding dingoes on Fraser Island, Australia, in the same category. The Udawalawe situation also differs from 'opportunistic feeding' in that those engaged represented a cross section of the public and their main motivation was not a desire for 'wildlife interaction'.

The feeding of elephants at Udawalawe was mainly motivated by culture and religion. While the Judeo-Christian view of animals as subordinate to humans prevails in the west, animals may be considered equal or revered as gods in the east (Orams 2002). Examples include benevolence towards all life espoused by Buddhist philosophy and Ganesh (elephant god) worship in Hinduism. The sharing of food is central to human sociality (Orams 2002). Giving food as alms is considered a meritorious act in eastern cultures and religions.
Offering of food to deities and their consumption by animals and/or directly feeding animals to gain spiritual merit is common in Sri Lanka and other Asian countries, such as India, Nepal (Jones-Engel et al. 2006), Indonesia (Lane et al. 2011b) and Thailand (Eudey 1994). We suggest that such activities represent a fifth type of wildlife feeding that could be termed 'spiritual'.

\section{Impacts on conservation}

Sri Lankan National Parks including Udawalawe are established in a conventional exclusionary top-down approach and governed in a command and control style. Authorities' view of feeding elephants and revenue earning by local communities is coloured by this background. However, stakeholder engagement is central to modern conservation thinking (Sterling et al. 2017) and local community participation in protected area decision-making fosters positive relationships (Andrade and Rhodes 2012). Protected area outreach, consisting of mutually beneficial problem resolution and deriving community benefits from protected area resources, is an important aspect of participatory natural resource management (Venter and Breen 1998). In Sri Lanka, outreach is mostly limited to environmental education and handouts, hence their long-term conservation benefit is debatable. Such programs have also been conducted around the Udawalawe National Park by the Wildlife Department (DWC 2010). In contrast, feeding fence elephants was easily identifiable with conservation by stakeholders and brought tangible ongoing and sustainable benefits to local communities, hence was an ideal outreach initiative.

The population of Sri Lanka is about $77 \%$ rural (Anon. 2015). Given that elephants and people share $44 \%$ of Sri Lanka's landscape (Fernando et al. in press), many rural folks would live in areas with elephants. Their usual relationship with wild elephants is entirely conflictive, with elephants raiding crops, people confronting them with aggression and elephants reciprocating in kind (Fernando et al. in press). At Udawalawe, the same people engaged in a relationship that was diametrically opposite, were seeing the elephants in a different light and willingly offering them food.

Extinction of experience of nature also results in reduced affinity to and interest in nature, valuing it less and decreased participation in pro-environmental behaviour (Cox and Gaston 2018). Seeing and engaging with the fence elephants is a memorable, personal nature experience. Therefore, a few thousand people a day enjoying such an experience would greatly benefit conservation.

\section{Management}

Orams (2002) suggests categorising management of wildlife feeding as 'prohibition', 'manage' and 'ignore'. Initially, the 
Wildlife Department ignored the activity, which led to its proliferation. Then, they banned it with steady escalation of punitive actions against the elephants. Our data in 2019 show that feeding continued in spite of all these efforts. Pursuit of prevention is the most likely future direction and may keep feeding to a low level, but is unlikely to eliminate it. However, it will require intensification of confronting and harassing the elephants, which may lead to reciprocal aggression by elephants, greater danger to people and perhaps more raiding. Since both ignoring and prohibiting have been tried and have failed, it seems prudent to explore its management.

\section{Turning a problem into a benefit}

The Udawalawe elephant feeding falls under the 'unstructured' category of wildlife feeding as defined by Newsome and Rodger (2008). Some unstructured feeding events have been converted to well-managed structured programs as in dolphin feeding at Monkey Mia, which became a multimillion-dollar tourism industry (Newsome and Rodger 2008). Similarly Barbary macaques in Gibraltar, provisioned since 1915, draw three-quarters of a million tourists annually (Unwin and Smith 2010). Through ticket sales alone, whale shark provisioning in the Philippines brings annual economic benefits amounting to around 4 million dollars to local communities (Meekan and Lowe 2019).

Identifying the involvement of a specific area, controlling feeding and education are important in converting unstructured feeding to structured programs (Newsome and Rodger 2008). The Udawalawe elephant feeding is already limited to a specific area. Local vendors benefitted from the activity, hence could be recruited to help control it. Creating awareness and its joint management with the community would make for an ideal outreach program. Managing the activity could also ensure unsuitable items are not offered to elephants. Therefore, in every aspect, the Udawalawe elephant feeding lends itself to being converted to a structured program.

Contrary to expectations, we found little evidence that provisioning was detrimental to wild animals in general and most negative impacts speculated on in the literature were not applicable to the feeding of elephants in Udawalawe. Our data shows that the activity was of great economic benefit to communities adjacent to the protected area and that an extensive cross section of the public benefitted by engaging in the activity. Therefore, we surmise that its impact on conservation is positive. If managed properly, the activity has tremendous tourist potential that could be significant nationally. We conclude that feeding of wild elephants by the general public at Udawalawe is a unique human-wildlife interaction and that all evidence indicates its managed continuation as the most beneficial future direction.
Acknowledgements We would like to thank Madusha Jayalath for keeping records of sales. We thank W.M.S. Wanigasekara, H.K. Janaka, Channa de Silva and Beatrice Hagmann for help with monitoring the elephants and Ashoka Ranjeewa for pictures of park elephants. We are grateful to Anoma Edirisooriya for entering the survey data. The very helpful comments of the anonymous reviewer are greatly appreciated.

Authors' contributions Study design: PF and JP; fieldwork: PF, SKKE and JP; data analysis and writing: PF and JP.

Funding Open access funding provided by University of Zurich. This study was funded by the Abraham Foundation.

Data availability Not applicable.

\section{Compliance with ethical standards}

Conflict of interest The authors declare that they have no conflict of interest.

Ethics approval Not applicable.

Consent to participate Not applicable.

Consent for publication Not applicable.

Code availability Not applicable.

Open Access This article is licensed under a Creative Commons Attribution 4.0 International License, which permits use, sharing, adaptation, distribution and reproduction in any medium or format, as long as you give appropriate credit to the original author(s) and the source, provide a link to the Creative Commons licence, and indicate if changes were made. The images or other third party material in this article are included in the article's Creative Commons licence, unless indicated otherwise in a credit line to the material. If material is not included in the article's Creative Commons licence and your intended use is not permitted by statutory regulation or exceeds the permitted use, you will need to obtain permission directly from the copyright holder. To view a copy of this licence, visit http://creativecommons.org/licenses/by/4.0/.

\section{References}

Abeysinghe KS, Perera ANF, Pastorini J, Isler K, Mammides C, Fernando P (2017) Gastrointestinal strongyle infections in captive and wild elephants in Sri Lanka. Gajah 46:21-27

Altmann J, Muruthi P (1988) Differences in daily life between semiprovisioned and wild-feeding baboons. Am J Primatol 15: 213-221

Andrade GSM, Rhodes JR (2012) Protected areas and local communities: an inevitable partnership toward successful conservation strategies? Ecol Soc 17(4):e14

Anon. (2015) Household income and expenditure survey 2012/2013. Final Report. Department of Census and Statistics, Sri Lanka. http://www.statistics.gov.lk/HIES/HIES2012_13FinalReport.pdf. Accessed 9 May 2020.

Baskaran N, Balasubramanian M, Swaminathan S, Desai AA (2010) Feeding ecology of the Asian elephant Elephas maximus Linnaeus in the Nilgiri Biosphere Reserve, Southern India. J Bombay Nat Hist Soc 107:3-13 
Bauer SA, Arndt TP, Leslie KE, Pearl DL, Turner PV (2011) Obesity in rhesus and cynomolgus macaques: a comparative review of the condition and its implications for research. Comp Med 61:514-526

Boutin S (1990) Food supplementation experiments with terrestrial vertebrates: patterns, problems, and the future. Can J Zool 68:203-220

Brittingham MC, Temple SA (1992) Does winter bird feeding promote dependency? J Field Ornithol 63:190-194

Christiansen F, McHugh KA, Bejder L, Siegal EM, Lusseau D, McCabe EB, Lovewell G, Wells RS (2016) Food provisioning increases the risk of injury in a long-lived marine top predator. R Soc Open Sci 3: e160560

Cox DTC, Gaston KJ (2018) Human-nature interactions and the consequences and drivers of provisioning wildlife. Phil Trans R Soc B 373:e20170092

Cross PC, Edwards WH, Scurlock BM, Maichak EJ, Rogerson JD (2007) Effects of management and climate on elk brucellosis in the greater Yellowstone ecosystem. Ecol Appl 17:957-964

de Silva S, Ranjeewa ADG, Weerakoon D (2011) Demography of Asian elephants (Elephas maximus) at Udawalawe National Park, Sri Lanka based on identified individuals. Biol Conserv 144:17421752

Déaux EC, Crowe T, Charrier I (2018) Recreational fishing alters dingo foraging behavior on Fraser Island. J Wildl Manage 82:85-92

Dubois S, Fraser D (2013a) A framework to evaluate wildlife feeding in research, wildlife management, tourism and recreation. Animals 3: 978-994

Dubois S, Fraser D (2013b) Local attitudes towards bear management after illegal feeding and problem bear activity. Animals 3:935-950

DWC (2010) Performance report 2010. Department of Wildlife Conservation, Battaramulla http://www.dwc.gov.lk/Aoldsite/ documents/Performance Report 2010.pdf. Accessed 9 May 2020.

Eisenberg JF (1980) Ecology and behavior of the Asian elephant. Elephant 1(5):36-56

Ekanayaka SKK, Campos-Arceiz A, Rupasinghe M, Pastorini J, Fernando P (2011) Patterns of crop raiding by Asian elephants in a human-dominated landscape in southeastern Sri Lanka. Gajah 34: $20-25$

Eudey AA (1994) Temple and pet primates in Thailand. Rev Ecol (Terre Vie) 49:273-280

Fa JE (1992) Visitor-directed aggression among the Gibraltar macaques. Zoo Biol 11:43-52

Fernando P (2015) The starving elephants of Udawalawe. Sanctuary Asia 35(5) https://www.sanctuaryasia.com/magazines/conservation/ 9933-the-starving-elephants-of-udawalawe.html. Accessed 9 May 2020.

Fernando P, Lande R (2000) Molecular genetic and behavioral analysis of social organization in the Asian elephant (Elephas maximus). Behav Ecol Sociobiol 48:84-91

Fernando P, Janaka HK, Ekanayaka SKK, Nishantha SG, Pastorini J (2009) A simple method for assessing elephant body condition. Gajah 31:29-31

Fernando P, Janaka HK, Prasad T, Pastorini J (2010) Identifying elephant movement patterns by direct observation. Gajah 33:41-46

Fernando P, Jayewardene J, Prasad T, Hendavitharana W, Pastorini J (2011) Current status of Asian elephants in Sri Lanka. Gajah 35: 93-103

Fernando P, De Silva MKCR, Jayasinghe LKA, Janaka HK, Pastorini J (in press) First country-wide survey of the endangered Asian elephants: towards better conservation and management in Sri Lanka. Oryx (in press).:1-10. https://doi.org/10.1017/S0030605318001254

Foroughirad V, Mann J (2013) Long-term impacts of fish provisioning on the behavior and survival of wild bottlenose dolphins. Biol Conserv 160:242-249

Fuller RA, Warren PH, Armsworth PR, Barbosa O, Gaston KJ (2008) Garden bird feeding predicts the structure of urban avian assemblages. Divers Distrib 14:131-137
Geist V (2011) Wildlife habituation: advances in understanding and management application. Human-Wildlife Interactions 5:9-12

Godbois IA, Conner LM, Warren RJ (2004) Space-use patterns of bobcats relative to supplemental feeding of northern bobwhites. J Wildl Manage 68:514-518

Gray RM, Vaughan MR, McMullin SL (2004) Feeding wild American black bears in Virginia: a survey of Virginia bear hunters, 1998-99. Ursus 15:188-196

Green R, Giese M (2004) Negative effects of wildlife tourism on wildlife. In: Higginbottom $\mathrm{K}$ (ed) Wildlife tourism, impacts, management and planning. Common Ground Publishing Pty Ltd, Sydney, pp 81-97

Gundersen H, Andreassen HP, Storaas T (2004) Supplemental feeding of migratory moose Alces alces: forest damage at two spatial scales. Wildl Biol 10:213-223

Higginbottom K, Tribe A (2004) Contributions of wildlife tourism to conservation. In: Higginbottom K (ed) Wildlife tourism, impacts, management and planning. Common Ground Publishing Pty Ltd, Sydney, pp 99-123

Hill DA (1999) Effects of provisioning on the social behaviour of Japanese and rhesus macaques: implications for socioecology. Primates 40:187-198

Hollister-Smith JA, Poole JH, Archie EA, Vance EA, Georgiadis NJ, Moss CJ, Alberts SC (2007) Age, musth and paternity success in wild male African elephants, Loxodonta africana. Anim Behav 74: 287-296

Ishigame G, Baxter GS, Lisle AT (2006) Effects of artificial foods on the blood chemistry of the Australian magpie. Austral Ecol 31:199-207

Johnson HE, Lewis DL, Verzuh TL, Wallace CF, Much RM, Willmarth LK, Breck SW (2018) Human development and climate affect hibernation in a large carnivore with implications for human-carnivore conflicts. J Appl Ecol 55:663-672

Jones-Engel L, Engel GA, Heidrich J, Chalise M, Poudel N, Viscidi R, Barry PA, Allan JS, Grant R, Kyes R (2006) Temple monkeys and health implications of commensalism, Kathmandu, Nepal. Emerg Infect Dis 12:900-906

José-Domínguez JM, Huynen M-C, García CJ, Albert-Daviaud A, Savini T, Asensio N (2015) Non-territorial macaques can range like territorial gibbons when partially provisioned with food. Biotropica 47: 733-744

Kamal KB, Boug A, Brain PF (1997) Effects of food provisioning on the behaviour of commensal Hamadryas baboons Papio hamadryas, at Al Hada Mountain in western Saudi Arabia. Zoology in the Middle East 14:11-22

Knapp CR, Hines KN, Zachariah TT, Perez-Heydrich C, Iverson JB, Buckner SD, Halach SC, Lattin CR, Romero LM (2013) Physiological effects of tourism and associated food provisioning in an endangered iguana. Conserv Physiol 1:1-17

Kofron C (1999) Attacks to humans and domestic animals by the southern cassowary (Casuarius casuarius johnsonii) in Queensland, Australia. J Zool 249:375-381

Lane KE, Holley C, Hollocher H, Fuentes A (2011a) The anthropogenic environment lessens the intensity and prevalence of gastrointestinal parasites in Balinese long-tailed macaques (Macaca fascicularis). Primates 52:117-128

Lane KE, Lute M, Rompis A, Wandia IN, Putra GAA, Hollocher H, Fuentes A (2011b) Indonesian primates. Developments in Primatology: Progress and Prospects. In: Gursky-Doyen S, Supriatna J (eds) Pests, pestilence and people: the long-tailed macaque and its role in the cultural complexities of Bali. Springer, New York

Laroche RK, Kock AA, Dill LM, Oosthuizen WH (2007) Effects of provisioning ecotourism activity on the behaviour of white sharks Carcharodon carcharias. Mar Ecol Prog Ser 338:199-209

López G, López-Parra M, Fernández L, Martínez-Granados C, Martínez F, Meli ML, Gil-Sánchez JM, Viqueira N, Díaz-Portero MA, 
Cadenas R, Lutz H, Vargas A, Simón MA (2009) Management measures to control a feline leukemia virus outbreak in the endangered Iberian lynx. Anim Conserv 12:173-182

Lott DF (1988) Feeding wild animals: the urge, the interaction, and the consequences. Anthrozoös 1:255-257

Loveridge AJ, Reynolds JC, Milner-Gulland EJ (2009) Does sport hunting benefit conservation? In: Macdonald D, Service K (eds) Key topics in conservation biology. Wiley, Hoboken, pp 222-238

Maréchal L, Semple S, Majolo B, MacLarnon A (2016) Assessing the effects of tourist provisioning on the health of wild Barbary macaques in Morocco. PLoS ONE 11:e0155920

McKay GM (1973) Behavior and ecology of the Asiatic elephants in Southeastern Ceylon. Smithsonian Contributions to Zoology No. $125,1,113$.

McKinney T (2011) The effects of provisioning and crop-raiding on the diet and foraging activities of human-commensal white-faced capuchins (Cebus capucinus). Am J Primatol 73:439-448

Meekan M, Lowe J (2019) Does provisioning for tourism harm whale sharks at Oslob? A review of the evidence and reply to Zeigler et al. (2018). Tour Manag 75:626-629

Miller R, Kaneene J, Fitzgerald S, Schmitt S (2003) Evaluation of the influence of supplemental feeding of white-tailed deer (Odocoileus virginianus) on the prevalence of bovine tuberculosis in the Michigan wild deer population. J Wildl Dis 39:84-95

Newsome D, Rodger K (2008) To feed or not to feed: a contentious issue in wildlife tourism. In: Lunney D, Munn A, Meikle W (eds) Too close for comfort: contentious issues in human-wildlife encounters. Royal Zoological Society of New South Wales, Mosman, pp 255270

O'Leary R, Jones D (2006) The use of supplementary foods by Australian magpies Gymnorhina tibicen: implications for wildlife feeding in suburban environments. Austral Ecol 31:208-216

Orams MB (1995) Development and management of a feeding program for wild bottlenose dolphins at Tangalooma, Australia. Aquat Mamm 21:137-147

Orams MB (2002) Feeding wildlife as a tourism attraction: a review of issues and impacts. Tour Manag 23:281-293

Palomares F, López-Bao JV, Rodríguez A (2010) Feline leukaemia virus outbreak in the endangered Iberian lynx and the role of feeding stations: a cautionary tale. Anim Conserv 14:242-245

Ranjeewa ADG, Tharanga YJS, Sandanayake GHNA, Perera BV, Fernando P (2015) Camera traps unveil enigmatic crop raiders in Udawalawe, Sri Lanka. Gajah 42:7-14

Rankin CH, Abrams T, Barry RJ, Bhatnagar S, Clayton DF, Colombo J, Coppola G, Geyer MA, Glanzman DL, Marsland S, McSweeney FK, Wilson DA, Wu C-F, Thompson RF (2009) Habituation revisited: an updated and revised description of the behavioral characteristics of habituation. Neurobiol Learn Mem 92:135-138

Rogers LL, Mansfield SA (2011) Misconceptions about black bears: a response to Geist (2011). Human-Wildlife Interactions 5:173-176

Rushen J, Taylor AA, de Passille AM (1999) Domestic animals' fear of humans and its effect on their welfare. Appl Anim Behav Sci 65: 285-303

Ryan C (1998) Saltwater crocodiles as tourist attractions. J Sust Tour 6: 314-327
Schmitz OJ (1990) Management implications of foraging theory: evaluating deer supplemental feeding. J Wildl Manag 54:522-532

Semeniuk CAD, Speers-Roesch B, Rothley KD (2007) Using fatty-acid profile analysis as an ecologic indicator in the management of tourist impacts on marine wildlife: a case of stingray-feeding in the Caribbean. Environ Manag 40:665-677

Sharpe LL, Clutton-Brock TH, Brotherton PNM, Cameron EZ, Cherry MI (2002) Experimental provisioning increases play in free-ranging meerkats. Anim Behav 64:113-121

Sorensen A, van Beest FM, Brook RK (2014) Impacts of wildlife baiting and supplemental feeding on infectious disease transmission risk: a synthesis of knowledge. Prev Vet Med 113:356-363

Sterling EJ, Betley E, Sigouin A, Gomez A, Toomey A, Cullman G, Malone C, Pekor A, Arengo F, Blair M, Filardi C, Landrigan K, Porzecanski AL (2017) Assessing the evidence for stakeholder engagement in biodiversity conservation. Biol Conserv 209:159-171

Stringham SF (2011) Aggressive body language of bears and wildlife viewing: a response to Geist (2011). Human-Wildlife Interactions $5: 177-191$

Strum SC (2010) The development of primate raiding: Implications for management and conservation. Int J Primatol 31:133-156

Sukumar R (1995) Elephant raiders and rogues. Natural History 7:52-61

Tate J (1983) A profile of panhandling black bears in the Great Smoky Mountains National Park. PhD dissertation, University of Tennessee.

Tollington S, Greenwood A, Jones CG, Hoeck P, Chowrimootoo A, Smith D, Richards H, Tatayah V, Groombridge JJ (2015) Detailed monitoring of a small but recovering population reveals sublethal effects of disease and unexpected interactions with supplemented feeding. J Anim Ecol 84:969-977

Treves A (2009) Hunting for large carnivore conservation. J Appl Ecol 46:1350-1356

Unwin T, Smith A (2010) Behavioral differences between provisioned and non-provisioned Barbary macaques (Macaca sylvanus). Anthrozoös 23(2):109-118

Usui R, Sheeran LK, Li J, Sun L, Wang X, Pritchard AJ, DuVall-Lash AS, Wagner RS (2014) Park rangers' behaviors and their effects on tourists and Tibetan Macaques (Macaca thibetana) at Mt. Huangshan, China. Animals 4:546-561

Vancuylenberg BWB (1977) Feeding behaviour of the Asiatic elephant in Southeast Sri Lanka in relation to conservation. Biol Conserv 12: $33-54$

Venter AK, Breen CM (1998) Partnership forum framework: participative framework for protected area outreach. Environ Manag 22:803815

Warren Y, Higham JP, Maclarnon AM, Ross C (2011) Crop-raiding and commensalism in olive baboons: the costs and benefits of living with humans. In: Sommer V, Ross C (eds) Primates of Gashaka. Developments in primatology: progress and prospects, Vol, vol 35. Springer, New York, pp 359-384

Publisher's note Springer Nature remains neutral with regard to jurisdictional claims in published maps and institutional affiliations. 